\title{
Evaluating the nutritional content of an insect-fortified food for the child complementary diet in Ghana
}

\author{
Megan E. Parker ${ }^{1 *}$ D, Stephanie Zobrist ${ }^{1}$, Herman E. Lutterodt ${ }^{2}$, Cyril R. Asiedu², Chantal Donahue ${ }^{1}$, Connor Edick ${ }^{1}$ \\ Kimberly Mansen ${ }^{1}$, Gretel Pelto ${ }^{3}$, Peiman Milani ${ }^{4}$, Shobhita Soor ${ }^{5}$, Amos Laar ${ }^{6}$ and Cyril M. Engmann 1,7,8
}

\begin{abstract}
Background: Due to rising food insecurity, natural resource scarcity, population growth, and the cost of and demand for animal proteins, insects as food have emerged as a relevant topic. This study examines the nutrient content of the palm weevil larva (Rhynchophorus phoenicis), a traditionally consumed edible insect called akokono in Ghana, and assesses its potential as an animal-source, complementary food.

Methods: Akokono in two "unmixed" forms (raw, roasted) and one "mixed" form (akokono-groundnut paste) were evaluated for their macronutrient, micronutrient, amino acid, and fatty acid profiles.

Results: Nutrient analyses revealed that a $32 \mathrm{~g}$ (2 tbsp.) serving of akokono-groundnut paste, compared to recommended daily allowances or adequate intakes (infant 7-12 months; child 1-3 years), is a rich source of protein (99\%; 84\%), minerals [copper (102\%; 66\%), magnesium (54\%; 51\%), zinc (37\%; 37\%)], B-vitamins [niacin (63\%; 42\%), riboflavin (26\%; 20\%), folate (40\%; 21\%)], Vitamin E (a-tocopherol) (440\%; 366\%), and linoleic acid (165\%; 108\%). Feed experiments indicated that substituting palm pith, the typical larval diet, for pito mash, a local beer production byproduct, increased the carbohydrate, potassium, calcium, sodium, and zinc content of raw akokono. Akokonogroundnut paste meets (within 10\%) or exceeds the levels of essential amino acids specified by the Institute of Medicine criteria for animal-source foods, except for lysine.

Conclusions: Pairing akokono with other local foods (e.g., potatoes, soybeans) can enhance its lysine content and create a more complete dietary amino acid profile. The promotion of akokono as a complementary food could play an important role in nutrition interventions targeting children in Ghana.
\end{abstract}

Keywords: Edible insects, Animal-source food, Complementary food, Nutrient profile, Ghana

\section{Background}

Maternal and child undernutrition remains pervasive in low- and middle-income countries (LMICs) and together constitutes the leading underlying cause of child morbidity and mortality [1]. Against a backdrop of global trends such as urbanization, growing populations, and rising incomes, the global food system faces the looming challenge of meeting the world's evolving nutritional needs [2]. Animal-source foods (ASFs) are important components of diverse diets, providing protein and essential

\footnotetext{
* Correspondence: mparker@path.org

'PATH, Maternal, Newborn, and Child Health and Nutrition, 2201 Westlake

Ave, Suite 200, Seattle, WA 98121, USA

Full list of author information is available at the end of the article
}

micronutrients that promote growth and development. Increasing evidence points to the positive impact of animalsource proteins on linear growth and physical and cognitive development in children [3-7]. The World Health Organization recommends that children 6 to 23 months of age consume ASFs daily [8]. Yet, ASFs are often costly and remain out of reach for many low-income households [5]. The global demand for ASFs in many LMICs is expected to rise substantially over the coming decades [9]. It is projected that current livestock production practices will be unable to sustainably meet this growing demand $[10,11]$. Thus, edible insects are emerging as a potential avenue to sustainably improve nutrition.

(c) The Author(s). 2020 Open Access This article is distributed under the terms of the Creative Commons Attribution 4.0 International License (http://creativecommons.org/licenses/by/4.0/), which permits unrestricted use, distribution, and 


\section{Insects as food}

Entomophagy, the consumption of insects as food, is a longstanding practice in many cultures around the world and has played a role in the history of human nutrition. The Food and Agriculture Organization estimates that approximately 2 billion people worldwide consume insects as part of their diets, [12] and Jongema [13] has documented over 2000 species of edible insects consumed globally. In comparison to traditional livestock, edible insect production has the potential to positively contribute to environmental sustainability due to lower resource requirements, feed-conversion rates, and greenhouse gas emissions [14, 15].

In the context of locally-sourced diets in LMICs, where the burden of malnutrition is highest, edible insects can contribute essential nutrients necessary to augment dietary quality and diversity among individuals who primarily consume cereal-based foods [16]. However, the nutritional profiles of edible insects indicate substantial variability both between and within species $[17,18]$ and comprehensive analyses of both macronutrient and micronutrient content are lacking [19].

\section{The Ghanaian context}

Malnutrition remains a pressing concern in Ghana, where one-fifth (19\%) of children under five suffer from chronic malnutrition (stunting), 5\% suffer from acute malnutrition (wasting), and two-thirds (66\%) of children between 6 and 59 months of age are anemic [20]. The typical complementary diet of Ghanaian children 6 to 23 months is composed of grains, fruits and vegetables, roots and tubers, and some animal products; only $13 \%$ of children of this age met the criteria for a minimally acceptable diet [20].

In Ghana, edible insects are already included in certain traditional diets. In a countrywide survey of 2000 individuals, almost one-third reported consuming edible insects, the most common being the palm weevil larva (Rhynchophoris phoenicis) [21]. Palm weevil larvae, known locally as akokono in Ghana, are consumed across regions of Africa, Asia, and Latin America [12]. In Ghana, the akokono typically feed on the pith of palm trees that are felled for harvesting palm wine and, when farmed, can be available year round [22, 23]. When harvested for food, akokono is typically fried, roasted as a kebab, or boiled in a soup (personal communication with Aspire Food Group, June 2017). According to a recent study, akokono was largely perceived to be an acceptable complementary food source by caregivers in the Brong-Ahafo Region of Ghana [22].

Previous studies investigating the nutritional composition of palm weevil larvae have typically reported high protein, fat, and mineral content, but there is variability between studies [16, 24-31]. This variability may be explained by a number of factors, including differences in insect habitat, geographic location, developmental stage, and feed composition, as well as the study measurement methods [17]. To our knowledge, no studies to date have examined the nutritional profile of the palm weevil larva in Ghana.

\section{Purpose}

We hypothesize that the consumption of akokono could help infants and young children meet essential amino acid [32] and micronutrient requirements and offset the need for daily consumption of traditional ASFs. The purpose of this study is to examine the nutrient profile of akokono (raw, roasted) to characterize the potential of this insect as an ingredient in complementary foods. We aimed to evaluate akokono and akokono-fortified foods as alternatives to conventional ASFs and examine the composition of their nutrient profiles based on feed type.

\section{Key messages}

- Akokono is a good source of several essential nutrients including protein, fat, zinc, and B-vitamins that are important for child growth and development.

- Combining akokono with local groundnuts can improve the amino acid and vitamin profiles of the nut-based food.

- Substituting the traditional feed substrate of palm pith with pito mash improves both the macronutrient and micronutrient profile of akokono.

- Optimizing the nutrient content of this insect via manipulation of feed substrate is an area in need of further research.

- Akokono has the potential to improve child health and nutrition outcomes and can be incorporated into nutrition interventions.

\section{Methods}

We examined the nutrient profile of akokono in two "unmixed" forms: raw and roasted. Additionally, three "mixed" akokono products were developed at the Kwame Nkrumah University of Science and Technology (KNUST): akokono flour, akokono-yam biscuit, and akokono-groundnut paste. The akokono-groundnut paste was chosen by the lead food technologist as the most promising food product for further testing and development as a potential child complementary food. Macronutrient composition, amino acid profile, fatty acid profile, mineral, and vitamin tests were conducted on these three forms of akokono as described below. Additionally, we measured the macronutrient and mineral composition of raw akokono fed two different types of feed materials, pito mash and palm pith, as well as that of the feed materials themselves. 
Macronutrient composition, amino acid profile, fatty acid profile, and mineral tests (except for iron) were conducted at KNUST in Ghana (described below). All tests conducted at KNUST represent the mean of duplicate analysis. Eurofins Scientific performed all the vitamin tests and examined the iron content of raw akokono, roasted akokono, and akokono-groundnut paste; the Eurofins results represent the mean of triplicate analysis (described below). KNUST used identical macronutrient and mineral testing procedures on the akokono and the feed materials (pito mash, palm pith).

\section{Preparation}

The akokono were bred in a warehouse in the Ashanti Region, fed with palm pith and sugar water, and procured from the Aspire Food Group facility in Kumasi. At the time of testing, akokono were between 28 and 35 days old (same development stage). Roasted samples were prepared by first pan-frying the akokono for $5 \mathrm{~min}$ followed by dry roasting at low heat for $15 \mathrm{~min}$. Using a recipe created at the KNUST food technology laboratory, the akokono-groundnut paste was produced by mixing and then milling dry-roasted akokono (30\%) together with local groundnuts (70\%) and adding a small amount of canola oil ( $2 \mathrm{~mL}$ oil per $100 \mathrm{~g}$ paste) to improve the organoleptic properties of the final product. Finally, KNUST tested the akokono-groundnut paste to assess shelf-life stability, microbial safety, and chemical deterioration of the product at 0,7 , and 14 days as required by the Ghana Food and Drugs Authority (FDA). The safety data satisfied the Ghana Standards Authority (GSA) requirements for similar groundnut-based products (data not presented herein) [33]. To test the feed materials, palm pith was harvested from purchased felled palm trees in the Ashanti Region, and the pito mash, a by-product of local pito (beer) brewing, was purchased from a local market.

\section{Proximate (macronutrient) analysis}

AOAC standard methods [34] were used to determine the proximate composition (moisture, ash, crude fat, protein, and fiber) of the akokono samples in duplicate. Significant differences between the macronutrient contents of the three forms of akokono were analyzed using one-way ANOVAs.

\section{Amino acid profile}

The amino acid content was determined by first digesting the sample for $24 \mathrm{~h}$ at $110{ }^{\circ} \mathrm{C}$ using $37 \% \mathrm{HCl}$. Precolumn derivatization was done using $o$-phthalaldehyde 3-mercaptopropionic acid and 9-fluroenylmethyl chloroformate according to the method described by Schwarz, Roberts, \& Pasquali [35]. An aliquot of $100 \mu \mathrm{L}$ was injected into a Shimadzu high-performance liquid chromatography (HPLC) fitted with a Shimadzu 10AxL Fluorescence detector.
Mobile phase A was composed of $40 \mathrm{mM} \mathrm{CH} \mathrm{CH}_{3} \mathrm{COONa}$ at pH7.8 and mobile phase $\mathrm{B}$ composed of $\mathrm{CH}_{3} \mathrm{CN}$ : $\mathrm{CH}_{3} \mathrm{OH}: \mathrm{H}_{2} \mathrm{O}(45: 45: 10 \mathrm{v} / \mathrm{v} / \mathrm{v})$ at a flow rate of $1 \mathrm{ml} / \mathrm{min}$, passed through a Phenomenex column $(3.5 \mu \mathrm{m}, 4.6 \mathrm{~mm}$ ID, $15 \mathrm{~cm}$ ) at $40^{\circ} \mathrm{C}$ with run time of $60 \mathrm{~min}$ at the following wavelengths: Exitation: $340 \mathrm{~nm}$; Emission: $450 \mathrm{~nm}$.

A gradient elution program was used as described herein: 0 to $10 \mathrm{~min}$ (20\% mobile phase B), 10 to $20 \mathrm{~min}$ (50\% mobile phase B), 20 to 30 min (60\% mobile phase B), 30 to $35 \mathrm{~min}$ ( $80 \%$ mobile phase B), 35 to $40 \mathrm{~min}$ (100\% mobile phase B), and 40 to 60 min (20\% mobile phase B). Samples were analyzed in duplicate, and results expressed as $\mathrm{g}$ amino acid per $100 \mathrm{~g}$ total amino acids.

\section{Fatty acid profiles}

The triglyceride profile was determined by HPLC. The analysis was carried out using a HPLC (Infinity Series 1260, Aligent Technologies, Germany) fitted with an auto sampler and a Refractive Index Detector. The Hypersil ODS C-18 column at ambient temperature was used with mobile phase of Acetonitrile: Acetone (37.5:62.5) at flow rate of 1.5. The elution program was isocratic. The purpose of this analysis was to characterize the fatty acid composition. Using mole ratio, the concentration of each component fatty acid was calculated for each triglyceride [36]. All samples were analyzed in duplicate.

\section{Mineral analysis}

The mineral analysis of iron, calcium, magnesium, zinc, and copper was conducted with atomic absorption spectroscopy [37]. The samples were dry-ashed in a muffle furnace at $550{ }^{\circ} \mathrm{C}$ for $6 \mathrm{~h}$. The minerals were extracted from ash with $20 \mathrm{~mL}$ of $2.50 \% \mathrm{HCl}$ and heated in a steam bath to reduce the volume to $8.0 \mathrm{~mL}$, which was transferred quantitatively to a $50 \mathrm{~mL}$ volumetric flask and diluted to volume using deionized water. The extracts were stored in dry, clean plastic sample bottles, and the mineral concentrations were determined using an atomic absorption spectrophotometer. Potassium was determined with the flame photometric method [38] using a low temperature direct reading single channel emission flame photometer. Significant differences between the mineral contents of the three forms of akokono were analyzed using one-way ANOVAs.

\section{Vitamin determination \\ Vitamin a}

Vitamin A was released from the sample by alkaline hydrolysis using ethanolic potassium hydroxide solution and extracted three times with hexane:ethylacetate (85: 15 volume/volume \%). The determination was carried out by normal-phase chromatography (NP-HPLC) with ultraviolet/diode array detector (DAD) at $325 \mathrm{~nm}$ (EN 12823-1:2014) [39]. 


\section{Vitamin B1 (thiamine)}

Thiamine was extracted from the sample in an autoclave using acid hydrolysis and quantified by reverse phase chromatography (RP-HPLC) coupled with a fluorescence detector (Ex.: $368 \mathrm{~nm}, \mathrm{Em} .: 440 \mathrm{~nm}$ ) after post-column oxidation to thiochrome (EN 14122:2006 with modification) [40].

\section{Vitamin B2 (riboflavin)}

Riboflavin was extracted from the sample in an autoclave using acid hydrolysis and quantified by RP-HPLC coupled with a fluorescence detector (Ex.: $468 \mathrm{~nm}$, Em $520 \mathrm{~nm}$ ) (EN 14152:2006 with modification) [41].

\section{Vitamin B3 (niacin)}

Niacin was calculated as the sum of nicotinic acid and nicotinamide. The two compounds were extracted from the sample in a mild hydrochloric solution at $100^{\circ} \mathrm{C}$, the $\mathrm{pH}$ of the extract was adjusted to $\mathrm{pH} 4.5$ with sodium acetate followed by a filtration.

\section{Vitamin B6}

To determine vitamin B6, the European Union reference method for the determination of vitamin B6 in foodstuff (EN 14164-2008) was used with modification [42]. Briefly, the sample was hydrolysed in an autoclave followed by enzymatic dephosphorylation, reacting with glyoxylic acid in the presence of $\mathrm{Fe}^{2+}$ as a catalyst to transform pyridoxamine into pyridoxal, which is then reduced to pyridoxine by the action of sodium borohydride in alkaline medium. Total pyridoxine was quantified by RP-HPLC with a fluorescence detector (Ex: 290 nm, Em: 395 nm).

\section{Folate}

Folate was extracted from the sample in an autoclave using a buffer solution, followed by an enzymatic digestion with human plasma and pancreas $\mathrm{V}$, and finally by a second autoclave treatment. After dilution with basal medium containing all required growth nutrients, except folic acid, the growth response of Lactobacillus rhamnosus (ATCC 7469) to extracted folate was measured turbidimetrically and compared to calibration solutions with known concentrations [43].

\section{Vitamin B12}

Vitamin B12 was extracted from the sample in an autoclave using a buffered solution. After dilution with basal medium (containing all required growth nutrients except cobalamin) the growth response of Lactobacillus leichmanii (ATCC 7830) to extracted cobalamin was measured turbidimetrically. This was then compared to calibration solutions with known concentrations [44].

\section{Vitamim D3}

The samples were saponified in alcoholic potassium hydroxide solution and extracted with hexane: ethylacetate $(85: 15 \mathrm{v} / \mathrm{v} \%)$. The extract was concentrated and cleaned up by solid phase extraction (EN 12821:2009) [45]. The amount of vitamin D3 was determined by RP-HPLC with DAD $(265 \mathrm{~nm})$.

\section{Vitamin $E$}

Vitamin E was released from the sample by alkaline hydrolysis using ethanolic potassium hydroxide solution and extracted three times with hexane:ethylacetate (85: $15 \mathrm{v} / \mathrm{v} \%)$. Quantification was carried out by NP-HPLC with a fluorescence detector (Ex/EM $290 \mathrm{~nm} / 327 \mathrm{~nm}$ ) (EN 12822:2014) [46].

Significant differences between the vitamin contents of the three forms of akokono were analyzed using one-way ANOVAs.

\section{Ethics approval and consent to participate}

This study was deemed not human subjects research by the PATH Research Determination Committee.

\section{Results}

\section{Macronutrients, minerals, and vitamins}

Table 1 presents the akokono nutrient content analysis from $100 \mathrm{~g}$ wet matter samples. The macronutrient profile of all forms of akokono was slightly more than half (53 to 56\%) fat, one-third (32 to 33\%) protein, and approximately one tenth (9 to 13\%) carbohydrate. The fiber content ranged from 4 to $10 \%$. The akokonogroundnut paste product had a slightly lower fat concentration than the unmixed forms of akokono, and similar protein and higher carbohydrate content.

In unmixed forms, akokono is richest in magnesium and potassium, followed by calcium, zinc, iron, and copper. When roasted akokono was combined with groundnut paste (and canola oil), the content of all analyzed minerals increased.

Of the vitamins present in akokono, the highest concentrations were observed for vitamin $E$ ( $\alpha$-tocopherol) and niacin. There were small but significant amounts of thiamine, riboflavin, vitamin B6, folate, and vitamin B12 in all akokono samples; vitamin A and vitamin D3 were not present. When roasted akokono was combined with the groundnut paste and canola oil, vitamin E ( $\alpha$-tocopherol) and niacin concentrations increased, and thiamine, riboflavin, folate, vitamin B6 and vitamin B12 decreased. Roasted akokono alone had significantly greater concentrations of thiamine, riboflavin, and vitamin B-12 than when it was combined with groundnut paste and canola oil into a paste.

Table 2 provides a closer examination of the macronutrient and micronutrient contribution of one serving size 
Table 1 Proximate, mineral, and vitamin profiles of three forms of akokono ${ }^{\ddagger}$

\begin{tabular}{|c|c|c|c|}
\hline & Raw & Roasted & Akokono-Groundnut Paste \\
\hline \multicolumn{4}{|l|}{ Proximate $^{1}$} \\
\hline & $\mathrm{g} / 100 \mathrm{~g}$ & $g / 100 \mathrm{~g}$ & $g / 100 \mathrm{~g}$ \\
\hline Ash (\%) & $3.93 \pm 0.13^{\mathrm{a}}$ & $2.65 \pm 0.09^{b}$ & $2.67 \pm 0.19^{b}$ \\
\hline Fat (\%) & $52.72 \pm 1.86^{\mathrm{a}}$ & $53.04 \pm 1.87^{\mathrm{a}}$ & $46.34 \pm 2.31^{b}$ \\
\hline Protein (\%) & $32.83 \pm 1.16^{\mathrm{a}}$ & $31.58 \pm 1.11^{\mathrm{a}}$ & $34.15 \pm 1.71^{b}$ \\
\hline Carbohydrate (\%) & $10.52 \pm 0.37^{a}$ & $12.73 \pm 0.45^{b}$ & $16.84 \pm 0.78^{c}$ \\
\hline Fiber (\%) & $9.61 \pm 0.34^{\mathrm{a}}$ & $4.52 \pm 0.16^{b}$ & $3.94 \pm 0.21^{c}$ \\
\hline \multicolumn{4}{|l|}{ Minerals ${ }^{1}$} \\
\hline & $\mathrm{mg} / 100 \mathrm{~g}$ & $\mathrm{mg} / 100 \mathrm{~g}$ & $\mathrm{mg} / 100 \mathrm{~g}$ \\
\hline $\operatorname{Iron}^{2}$ & $0.85 \pm 0.17^{\mathrm{a}}$ & $1.30 \pm 0.26^{b}$ & $1.50 \pm 0.30^{c}$ \\
\hline Potassium & $16.90 \pm 0.85^{a}$ & $13.90 \pm 0.70^{b}$ & $240.20 \pm 12.01^{c}$ \\
\hline Calcium & $4.60 \pm 0.23^{\mathrm{a}}$ & - & $42.90 \pm 2.15^{\mathrm{b}}$ \\
\hline Magnesium & $25.80 \pm 1.29^{a}$ & $23.30 \pm 1.17^{a}$ & $126.50 \pm 6.33^{b}$ \\
\hline Zinc & $3.60 \pm 0.18^{\mathrm{a}}$ & - & $3.50 \pm 0.18^{\mathrm{a}}$ \\
\hline Copper & $0.90 \pm 0.05^{\mathrm{a}}$ & $0.30 \pm 0.02^{b}$ & $0.70 \pm 0.04^{c}$ \\
\hline \multicolumn{4}{|l|}{ Vitamins $^{2}$} \\
\hline & $\mathrm{mg} / 100 \mathrm{~g}$ & $\mathrm{mg} / 100 \mathrm{~g}$ & $\mathrm{mg} / 100 \mathrm{~g}$ \\
\hline Vitamin A & $<0.021(\mathrm{LOQ})$ & $<0.021(\mathrm{LOQ})$ & $<0.021(\mathrm{LOQ})$ \\
\hline Thiamine & $0.12 \pm 0.02^{\mathrm{a}}$ & $0.22 \pm 0.04^{b}$ & $0.12 \pm 0.02^{\mathrm{a}}$ \\
\hline Niacin & $4.79 \pm 0.67^{\mathrm{a}}$ & $4.02 \pm 0.56^{\mathrm{a}}$ & $7.88 \pm 1.10^{b}$ \\
\hline Riboflavin & $0.60 \pm 0.10^{a}$ & $0.81 \pm 0.13^{\mathrm{a}}$ & $0.32 \pm 0.05^{b}$ \\
\hline Vitamin B6 & $0.18 \pm 0.03^{\mathrm{a}}$ & $0.27 \pm 0.04^{b}$ & $0.21 \pm 0.03^{b}$ \\
\hline Folate & $0.20 \pm 0.06^{\mathrm{a}}$ & $0.21 \pm 0.06^{\mathrm{a}}$ & $0.10 \pm 0.29^{a}$ \\
\hline Vitamin B12 & $0.02 \pm 0.00^{\mathrm{a}}$ & $0.02 \pm 0.01^{a}$ & $0.00 \pm 0.00^{b}$ \\
\hline Vitamin D3 & $<0.00025$ (LOQ) & $<0.00025(\mathrm{LOQ})$ & $<0.00025(\mathrm{LOQ})$ \\
\hline Vitamin E & $11.20 \pm 1.70^{\mathrm{a}}$ & $18.60 \pm 2.80^{\mathrm{a}}$ & $68.70 \pm 10.40^{b}$ \\
\hline
\end{tabular}

${ }^{1}$ Tests were conducted by Microbiology Lab of the Department of Biochemistry and Biotechnology at KNUST on dry matter akokono. Results represent means of duplicate analysis

${ }^{2}$ Tests were conducted by Eurofins Lab on original matter akokono. Results represent means of triplicate analysis

${ }^{\ddagger}$ Results are reported as mean $\pm \mathrm{sd}$. A one-way ANOVA was used to determine significant differences between the samples. Samples with different letter superscripts $(a, b, c)$ in the same row are significantly different $(p<0.05)$. The larval lifecycle stage was similar between all akokono tested.

LOQ: Limit of quantitation

$\checkmark$ Akokono-groundnut paste was made with roasted akokono

of akokono-groundnut paste to the child diet. One serving size of two tablespoons (approximately $32 \mathrm{~g}$ ) of akokono-groundnut paste contains enough protein to satisfy 99\% of an infant's (6 to 12 months) recommended dietary allowance (RDA) and $84 \%$ of a child's ( 1 to 3 years) RDA. It also provides half (49\%) of an infant's adequate intake (AI) recommendation for fat (AI for children 1 to 3 years not determined). However, the same serving size only provides 7 and 5\% of infant and child carbohydrate RDAs, respectively, and $7 \%$ of a child's AI level for fiber (AI for infants not determined). It is a rich source of certain minerals (infant 6 to 12 months, children 1 to 3 years): copper (102\% AI, 66\% RDA), magnesium (54\% AI, 51\% RDA), zinc (37\% RDA, 37\% RDA), potassium ( $11 \% \mathrm{AI}, 3 \% \mathrm{AI})$, iron (4\% RDA, 7\% RDA), and calcium (5\% AI, 2\% RDA). The paste also provides B-vitamins (infants 6 to 12 months, children 1 to 3 years): thiamine ( $13 \% \mathrm{AI}, 8 \% \mathrm{RDA})$, niacin $(63 \% \mathrm{AI}$, $42 \% \mathrm{RDA})$, riboflavin (26\% AI, 20\% RDA), vitamin B6 (22\% $\mathrm{AI}, 13 \% \mathrm{RDA})$, folate (40\% $\mathrm{AI}, 21 \% \mathrm{RDA})$, and vitamin $\mathrm{E}$ (a-tocopherol) (440\% AI, 366\% RDA).

\section{Amino acids}

Table 3 lists the concentrations of amino acids within two unmixed forms of akokono and the mixed akokono-groundnut paste in comparison to the concentration thresholds listed by the Institute of Medicine (IOM) for ASFs [47]. Concentrations of methionine and cysteine (sulfur amino acids) are examined together since methionine is often the most limiting amino acid in cereal grain-based diets, and cysteine is able to substitute for a portion of methionine's 
Table 2 The nutritional content of one serving** akokono-groundnut paste in comparison to the recommended dietary allowance (RDA) or adequate intake (Al) for children 6-12 months of age and 1-3 years of age

\begin{tabular}{|c|c|c|c|c|c|}
\hline & \multicolumn{2}{|c|}{$\mathrm{RDA}$ or $\mathrm{Al}{ }^{*}$ standard } & \multicolumn{3}{|c|}{ Akokono-groundnut Paste } \\
\hline & \multirow{2}{*}{$\begin{array}{l}6-12 \\
\text { months }\end{array}$} & \multirow{2}{*}{$\begin{array}{l}1-3 \\
\text { years }\end{array}$} & \multirow{2}{*}{$\begin{array}{l}32 \mathrm{~g} \\
\text { serving }\end{array}$} & \multicolumn{2}{|l|}{$\%$ RDA or $\% A l$} \\
\hline & & & & 6-12 months & $1-3$ years \\
\hline \multicolumn{6}{|l|}{ Macronutrients } \\
\hline Fat (g) & $30^{*}$ & ND & 14.83 & $49 \%$ & ND \\
\hline Protein (g) & 11 & 13 & 10.93 & $99 \%$ & $84 \%$ \\
\hline Carbohydrate (g) & $95^{*}$ & 130 & 5.39 & $6 \%$ & $4 \%$ \\
\hline \multicolumn{6}{|l|}{ Minerals } \\
\hline Iron (mg) & 11 & 7 & 0.48 & $4 \%$ & $7 \%$ \\
\hline Potassium (g) & $0.7^{*}$ & $3^{*}$ & 0.08 & $11 \%$ & $3 \%$ \\
\hline Calcium (mg) & $260^{*}$ & 700 & 13.73 & $5 \%$ & $2 \%$ \\
\hline Magnesium (mg) & $75^{*}$ & 80 & 40.48 & $54 \%$ & $51 \%$ \\
\hline Zinc (mg) & 3 & 3 & 1.12 & $37 \%$ & $37 \%$ \\
\hline Copper (mg) & $0.22^{*}$ & 0.34 & 0.22 & $102 \%$ & $66 \%$ \\
\hline \multicolumn{6}{|l|}{ Vitamins } \\
\hline Vitamin A (ug) & $500^{*}$ & 300 & 0.00 & $0 \%$ & $0 \%$ \\
\hline Thiamine (mg) & $0.30^{*}$ & 0.50 & 0.04 & $13 \%$ & $8 \%$ \\
\hline Niacin (mg) & $4^{*}$ & 6 & 2.52 & $63 \%$ & $42 \%$ \\
\hline Riboflavin (mg) & $0.4^{*}$ & 0.5 & 0.10 & $26 \%$ & $20 \%$ \\
\hline Vitamin B6 & $0.3^{*}$ & 0.5 & 0.07 & $22 \%$ & $13 \%$ \\
\hline Folate (ug) & $80^{*}$ & 150 & 32.00 & $40 \%$ & $21 \%$ \\
\hline Vitamin B12 (ug) & $0.5^{*}$ & 0.9 & 0.00 & $0 \%$ & $0 \%$ \\
\hline Vitamin D3 (ug) & 10 & 15 & 0.00 & $0 \%$ & $0 \%$ \\
\hline Vitamin E & $5^{*}$ & 6 & 21.98 & $440 \%$ & $366 \%$ \\
\hline \multicolumn{6}{|l|}{ Fatty acids } \\
\hline Linoleic acid & $4.6^{*}$ & $7^{*}$ & 7.58 & $165 \%$ & $108 \%$ \\
\hline
\end{tabular}

*Adequate intake (Al) values

${ }^{* *}$ One serving $=2$ tbsp, or approximately $32 \mathrm{~g}$ of akokono-groundnut paste $N D$ : Not determined

requirement. Phenylalanine and tyrosine (aromatic amino acids) are also examined together. While both are indispensable to human functions, phenylalanine must be consumed in the diet, but tyrosine can be generated from the hydroxylation of phenylalanine [32]. Roasted akokono meets or exceeds the IOM's concentration threshold for ASFs for four of the nine essential amino acids (histidine, isoleucine, phenylalanine + tyrosine, and valine), but concentrations of leucine, lysine, methionine + cysteine, threonine, and tryptophan fell short of the IOM threshold level. When akokono was combined with groundnut paste and canola oil, the concentrations of leucine, methionine + cysteine, threonine, and tryptophan increased to within $10 \%$ of the IOM threshold level; however, lysine content remained low. The concentrations of histidine, isoleucine, lysine, and phenylalanine + tyrosine were greater in unmixed akokono than the paste product. Akokono is also a source of seven non-essential amino acids, including alanine, arginine, aspartate, glutamate, glycine, proline, and serine (data not presented herein).

\section{Fatty acids}

Table 4 lists the fatty acid compositions of three different forms of akokono. The profiles of raw and roasted akokono respectively showed concentrations of 6.54 and $14.29 \mathrm{~g} / 100 \mathrm{~g}$ linoleic acid ( $n-6$ polyunsaturated fatty acid), 14.47 and $7.37 \mathrm{~g} / 100 \mathrm{~g}$ oleic acid, 19.95 and 14.97 $\mathrm{g} / 100 \mathrm{~g}$ myristic acid, and 19.52 and $13.87 \mathrm{~g} / 100 \mathrm{~g}$ palmitic acid. When combined with the groundnut paste and canola oil, fatty acid concentrations (g/ $100 \mathrm{~g}$ akokono) increased compared to roasted akokono for linoleic (omega-6) acid (23.69), stearic acid (1.67), and oleic acid (11.16), while decreasing for 
Table 3 Amino acid profile of three forms of akokono ${ }^{a}$ (mg/g protein), compared to the concentration of amino acids required to meet the IOM ASF definition

\begin{tabular}{|c|c|c|c|c|}
\hline \multirow[t]{2}{*}{ Essential amino acids } & Raw & Roasted & Akokono-groundnut paste & $\begin{array}{l}\text { Concentration of essential amino acids required } \\
\text { to meet IOM ASF definition }{ }^{\mathrm{b}}\end{array}$ \\
\hline & \multicolumn{4}{|c|}{ mg/g protein } \\
\hline Histidine & 52 & 50 & 32 & 18 \\
\hline Isoleucine & 50 & 57 & 41 & 25 \\
\hline Leucine & 40 & 21 & 51 & 55 \\
\hline Lysine & 40 & 39 & $36^{*}$ & 51 \\
\hline Methionine + Cysteine & 28 & 22 & 24 & 25 \\
\hline Phenylalanine + Tyrosine & 115 & 97 & 91 & 47 \\
\hline Threonine & 32 & 22 & 25 & 27 \\
\hline Tryptophan & - & 5 & 9 & 7 \\
\hline Valine & 35 & 36 & 40 & 32 \\
\hline \multicolumn{5}{|l|}{ Non-essential amino acids } \\
\hline Alanine & 108 & 140 & 69 & - \\
\hline Arginine & - & 44 & 92 & - \\
\hline Aspartic acid (Aspartate) & 47 & 46 & 94 & - \\
\hline Glutamic acid (Glutamate) & 121 & 138 & 170 & - \\
\hline Glycine & 37 & 31 & 48 & - \\
\hline Proline & 91 & 132 & 70 & - \\
\hline Serine & 108 & 140 & 69 & - \\
\hline
\end{tabular}

${ }^{\mathrm{a}}$ Values represent means of duplicate analysis

bInstitute of Medicine (IOM). (2005). Dietary reference intakes for energy, carbohydrate, fiber, fat, fatty acids, cholesterol, protein, and amino acids. Institute of

Medicine, The National Academies Press. Washington, D.C.

*Concentration of lysine in akokono -groundnut paste is more than 10\% below IOM ASF definition

ASF: Animal-source food

IOM Institute of Medicine

${ }^{\checkmark}$ Akokono-groundnut paste was made with roasted akokono

myristic and palmitic acids (1.51 and 5.96, respectively). The fatty acid concentration of linoleic acid exceeds the AI levels for infants (165\% AI) and children (108\% AI). AI levels for oleic acid, myristic acid, and palmitic acid have not been set.

\section{Feed experiment}

Table 5 shows the results of the akokono feed experiments. Akokono fed on pito mash had $>10 \%$ increased concentrations of carbohydrate, potassium, calcium, sodium, and zinc concentrations in comparison to those fed on palm pith. The protein and iron content remained consistent between the two groups, but the fat content was lower among akokono fed on pito mash. The pito mash itself contained a higher concentration of fat, protein, and all measured elements.

\section{Discussion}

This study presents the nutritional composition of palm weevil larvae (akokono), edible insects consumed in

Table 4 Fatty acid compositions of three forms of akokono ${ }^{a}$

\begin{tabular}{|c|c|c|c|c|c|c|}
\hline \multirow[t]{2}{*}{ Fatty acids ${ }^{b}$} & \multicolumn{2}{|l|}{ Raw } & \multicolumn{2}{|l|}{ Roasted } & \multicolumn{2}{|c|}{ Akokono-groundnut paste } \\
\hline & $\mathrm{g} / 100 \mathrm{~g}$ & $\mathrm{~g} / 32 \mathrm{~g}$ & $\mathrm{~g} / 100 \mathrm{~g}$ & $\mathrm{~g} / 32 \mathrm{~g}$ & $g / 100 \mathrm{~g}$ & $g / 32 g$ \\
\hline Linoleic acid & 6.54 & 2.09 & 14.29 & 4.57 & 23.69 & 7.58 \\
\hline Oleic acid & 14.47 & 4.63 & 7.37 & 2.36 & 11.16 & 3.57 \\
\hline Myristic acid & 19.95 & 6.38 & 14.97 & 4.79 & 1.51 & 0.48 \\
\hline Palmitic acid & 9.52 & 3.05 & 13.87 & 4.44 & 5.96 & 1.91 \\
\hline Stearic acid & 0 & 0 & 0 & 0 & 1.67 & 0.53 \\
\hline
\end{tabular}

${ }^{a}$ Values represent means of duplicate analysis

${ }^{b}$ Concentrations given in $\mathrm{g}$ fatty acid/g sample

${ }^{\vee}$ Akokono-groundnut paste was prepared with roasted akokono 
Table 5 Proximate and mineral content of akokono and feed materials

\begin{tabular}{|c|c|c|c|c|}
\hline & Palm pith & Akokono fed on palm pith & Pito mash & Akokono fed on pito mash \\
\hline \multicolumn{5}{|l|}{ Proximates $^{a}$} \\
\hline & $\mathrm{g} / 100 \mathrm{~g}$ & $\mathrm{~g} / 100 \mathrm{~g}$ & $g / 100 g$ & $\mathrm{~g} / 100 \mathrm{~g}$ \\
\hline Ash (\%) & 8.08 & 3.23 & 3.46 & 3.18 \\
\hline Fat (\%) & 0.69 & 50.29 & 7.83 & 42.43 \\
\hline Protein (\%) & 24.08 & 31.83 & 27.82 & 32.39 \\
\hline Carbohydrate (\%) & 67.15 & 14.65 & 60.89 & 22.00 \\
\hline \multicolumn{5}{|l|}{ Elements $^{\mathrm{b}}$} \\
\hline & $\mathrm{mg} / 100 \mathrm{~g}$ & $\mathrm{mg} / 100 \mathrm{~g}$ & $\mathrm{mg} / 100 \mathrm{~g}$ & $\mathrm{mg} / 100 \mathrm{~g}$ \\
\hline Iron & 0.48 & 1.69 & 0.69 & 1.75 \\
\hline Potassium & 721.92 & 26.02 & 1562.70 & 65.95 \\
\hline Calcium & 54.59 & 18.19 & 75.91 & 38.31 \\
\hline Sodium & 77.52 & 19.99 & 92.28 & 42.48 \\
\hline Zinc & 1.78 & 4.48 & 2.56 & 6.05 \\
\hline
\end{tabular}

${ }^{a}$ Data represent mean of duplicate analysis reported on dry matter basis

${ }^{b}$ Data represent mean of duplicate analysis

Ghana, and evaluates their adequacy as a complementary food, both alone and in combination with local groundnuts. We conclude that akokono alone does not provide a complete amino acid profile, but it does offer a significant amount of essential nutrients and can feasibly be integrated into agriculture and nutrition intervention strategies to address upstream determinants of health and nutrition. Furthermore, there is potential to improve the nutrient content of this food by manipulating feed inputs; however, further research in this area is warranted.

\section{Nutrient content}

Consistent with existing research, our analysis determined Ghanaian akokono to be a nutrient-rich, high fat, high protein food. Roasted akokono contains adequate amounts of four essential amino acids (histidine, isoleucine, phenylalanine + tyrosine, and valine) but inadequate amounts of five essential amino acids (e.g., leucine, lysine, methionine + cysteine, threonine, tryptophan). Combining akokono with groundnut paste and canola oil favorably affected both the amino acid and fatty acid composition of the food, increasing the ratio of essential to non-essential fatty acids and the ratio of unsaturated to saturated fatty acids (i.e., more linoleic and oleic acid, less myristic and palmitic acid), likely largely due to the composition of canola oil. In comparison to roasted akokono, the paste product had greater concentrations of all minerals analyzed but lower vitamin concentrations (except for vitamin $\mathrm{E}$ and niacin).

In contrast to studies examining the nutritional composition of the palm weevil larvae in other African countries, the greatest differences are seen in mineral content, which varies between studies, independent of geography. We hypothesize that the larval diet could be one explanation for the variation between protein, fat, and mineral content. Our feed experiment indicated that the akokono responded to different feed substrates with changes in macronutrient and micronutrient composition. However, multiple studies from Nigeria [26, 29, 30], where the palm weevil larva were fed only raphia palm pith, still observed significant variability in mineral content. Research by Reynolds et al. [48] in Uganda found vast heterogeneity in mineral content between 11 samples of pith from raphia palms, suggesting that nutrient variability among the same type of feed substrate, perhaps due to soil quality, could also contribute to differences in nutrient profiles between different insect samples. Variability may also be linked to the developmental stage of the larvae analyzed [17].

We found that one serving (approximately $32 \mathrm{~g}$ ) of a kokono-groundnut paste provided 6\% of the infant (6 to 12 months) iron RDA and 9\% of the child (1 to 3 years) iron RDA. However, akokono is a potential source of highly bioavailable iron. Heme-iron is present in insect cytochromes [49] and ferrous iron is carried by holoferritin molecules in the vacuolar system and hemolymph [50]. Both forms have greater bioavailability than the ferric iron most prevalent in non-heme source foods [51], and the absence of iron-binding plant origin compounds [52] could be advantageous for the absorption of iron from akokono. The properties of insect iron may explain results from previous studies, including a trial which found that caterpillar fortified cereal improved hemoglobin levels, ferritin levels, and anemia prevalence among 18-month-old infants, [53] and an in-vitro study that showed iron bioavailability of several insect species to be comparable with that of sirloin beef [54]. It is plausible that similar benefits could extend to akokono presupposing that their underlying biology is largely the same as that of other insects. 


\section{Adequacy as a complementary food}

In many low-resource settings, women and children are deficient in iron, zinc, and vitamin A, and often subsist on diets low in protein and essential fatty acids. The nutrient profile of akokono can augment the intakes of certain micronutrients and macronutrients that play important roles in development and immunity. At the same time, concentrations of these nutrients may be dependent on insect feed and rearing practices. Opportunities to optimize the nutrient content of this food is an area in need of further research.

Based on our findings, akokono does not meet all the requirements to be classified as an alternative ASF; however, it still holds promise as a component of the complementary diet to help meet nutritional requirements. Pairing akokono-groundnut paste with lysine-rich foods can provide a complete protein profile. For example, potatoes and soybeans are two locally produced foods that are high in lysine. Additionally, it is also significant that the akokono-groundnut paste product meets the GSA requirements for commercial peanut butter products and can be safely consumed without refrigeration for 14 days (data not included). This suggests that the akokonogroundnut paste could be consumed in settings that lack electricity, without any added risk relative to other commercial peanut butter products in Ghana.

\section{Policies on insects as food}

In Ghana, akokono has historically been harvested from palm trees; however, this practice has fallen out of favor among younger generations [22]. Recent efforts to stimulate the market have initiated the reintroduction of edible insects into the modern food supply in Ghana by way of microfarming. Forest foods can provide healthy additions to household diets and household microfarming can generate additional income; thus, opportunities for incorporating forest foods into nutrition policy and health intervention strategies should be further explored [55].

However, policies and legislation on insects as food are currently lacking on both national and international levels. While some institutions and policies, such as Ghana's FDA, do focus on food standards in Ghana, legislation is generally broad and does not offer guidelines specific to insects. Although unprocessed akokono is recognized as a safe, local, traditional food that has been consumed for generations, GSA certification is required for all processed akokono-based products. Building quality control mechanisms and risk mitigation strategies can help to inform the standards enforced and upheld by the Ghana FDA and the GSA to ensure food safety. There is a great need for unifying regulations and efforts focusing on the production and sale of insects for human consumption, both in
Ghana and internationally-particularly given their low environmental impact and potential to improve human nutrition.

\section{Limitations}

This study investigated the macronutrient and micronutrient content of a small sample of domestically microfarmed akokono. Future research, including studies with larger sample sizes and those testing akokono harvested from the wild, is needed to confirm our results. In addition, further research into different feed inputs and their associated impact on the insect's nutrient profile will continue to support both optimal insect nutrient content as well as inform low-environmental impact production efforts. Further analyses comparing the nutrient profile of akokono-fortified groundnut paste to that of groundnut paste alone may also provide additional insights. Acceptability studies, such as the one conducted by Bauserman et al., [56] are also warranted to further investigate consumer perceptions of akokonofortified commercial food products.

In addition to further characterizing the nutrient profiles of akokono and akokono-fortified foods, clinical research is also needed to determine the impacts of these foods on human health and nutrition outcomes. For example, Bauserman and colleagues [53] evaluated the efficacy of a caterpillar cereal on stunting and anemia in the Democratic Republic of the Congo.

Finally, it was a limitation of this study that we did not investigate the digestibility of protein from akokono, nor did we examine micronutrient bioavailability. Although information on insect protein quality is limited, several studies have calculated Protein Digestibility Corrected Amino Acid Scores for various insect species $[57,58]$. As such, insect protein quality and digestibility is an important area for future inquiry, particularly given the role of protein quality in early growth [59].

\section{Conclusion}

Although there is no one-size-fits-all solution to malnutrition, it is important that we continue to examine traditional practices-such as entomophagy-and their implications for human and planetary health. In this paper, we conclude that the promotion and uptake of akokono as a complementary food could address nutritional inadequacies in the Ghanaian diet. Further, our feed experiment demonstrates the potential for using recycled by-products as novel feed inputs to reduce the environmental impact of production and manipulate insect nutrient profiles. Implemented properly, nutrition and policy interventions involving akokono could also incorporate nutrition-sensitive strategies centered around women-led micro-farming to generate supplemental income while improving food security. 


\section{Abbreviations}

Al: Adequate Intake; ASF: Animal-source food; DAD: Diode array detector; FDA: Food and drug authority; GSA: Ghana standards authority; HPLC: Highperformance liquid chromatography; IOM: Institute of medicine: KNUST: Kwame Nkrumah University of Science and Technology; LMIC: Lowand middle-income country; LOQ: Limit of quantitation; ND: Not determined; NP: Normal-phase; RDA: Recommended dietary allowance; RP: Reverse phase

\section{Acknowledgements}

We thank Eurofins for conducting components of the analysis.

\section{Authors' contributions}

MEP, HEL, SS, AL, GP and PM made substantial contributions to study concept and design. HEL, CRA, and SS completed data collection and laboratory analysis. MEP, SZ, CRA, CE, KM, and CD interpreted the data and drafted the manuscript. PM, GP, KM, AL, and CME critically revised the manuscript. All authors gave final approval of the version to be published and agreed to be accountable for all aspects of the work.

\section{Funding}

This project was supported by a grant from the Bill \& Melinda Gates Foundation.

\section{Availability of data and materials}

All data generated or analyzed during this study are included in this published article [and its supplementary information files].

\section{Ethics approval and consent to participate}

This study was deemed not human subjects research by the PATH Research Determination Committee. Experimentation was only conducted on deceased insects.

\section{Consent for publication}

Experimentation was conducted on deceased insects thus consent for publication was not applicable.

\section{Competing interests}

SS is a founding member and Chief Impact Officer of Aspire Food Group. Aspire FG commercially farms palm weevil larvae in Ghana and directs a program to empower peri-rural farmers to raise palm weevils locally. The remaining authors declare that the research was conducted in the absence of any commercial or financial relationships that could be construed as a potential conflict of interest.

\section{Author details}

'PATH, Maternal, Newborn, and Child Health and Nutrition, 2201 Westlake Ave, Suite 200, Seattle, WA 98121, USA. ${ }^{2}$ Department of Food Science and Technology, Kwame Nkrumah University of Science and Technology, Kumasi, Ghana. ${ }^{3}$ Division of Nutritional Sciences, Cornell University, Ithaca, New York, USA. ${ }^{4}$ Sight and Life Foundation, Kaiseraugst, Switzerland. ${ }^{5}$ Aspire Food Group, Kumasi, Ghana. ${ }^{6}$ Department of Population, Family and Reproductive Health, School of Public Health, University of Ghana, Accra, Ghana. ${ }^{7}$ Department of Global Health, University of Washington, Seattle, Washington, USA. ${ }^{8}$ Department of Pediatrics, University of Washington \& Seattle Children's Hospital, Seattle, Washington, USA.

Received: 18 December 2018 Accepted: 27 January 2020 Published online: 02 April 2020

\section{References}

1. Black R, Victora C, Walker S, Bhutta Z, Christian P, Onis MD, et al. Maternal and child undernutrition and overweight in low-income and middleincome countries. Lancet. 2013 Aug 03;382(9890):427-51.

2. International Food Policy Research Institute (US). 2018 Global food policy report Washington (DC): International Food Policy Research Institute; 2018. p. 150.

3. Grace D, Dominguez-Salas P, Alonso S, Lannerstad M, Muunda E, Ngwili N, et al. The influence of livestock-derived foods on nutrition during the first 1,000 days of life. Nairobi (KE): ILRl; 2018. p. 82. Report No. 44

4. Dror DK, Allen LH. The importance of milk and other animal-source foods for children in low-income countries. Food Nutr Bull. 2011;32(3):227-43.
5. Headey D, Hirvonen K, Hoddinott J. Animal sourced foods and child stunting. Am J Agric Econ. 2018;100(5):1302-19.

6. lannotti LL, Lutter CK, Stewart CP, Riofrío CA, Malo C, Reinhart G, et al. Eggs in early complementary feeding and child growth: a randomized controlled trial. Pediatrics. 2017;140(1):e20163459.

7. Krebs NF, Mazariegos M, Tshefu A, Bose C, Sami N, Chomba E, et al. Meat consumption is associated with less stunting among toddlers in four diverse low-income settings. Food Nutr Bull. 2011;32(3):185-91.

8. Dewey K. Guiding principles for complementary feeding of the breastfed child. Pan American Health Organization: Washington (DC); 2003. p. 37.

9. Alexandratos N, Bruinsma J. World agriculture towards 2030/2050: the 2012 revision. Rome (IT): Food and Agriculture Organization of the United Nations; 2012. p. 146. ESA Working Paper No. 12-03

10. Steinfeld H, Gerber P, Wassenaar T, Castel V, Rosales M, de Haan C. Livestock's long shadow: environmental issues and options. Rome (IT): Food and Agriculture Organization of the United Nations; 2006. p. 26

11. Wu G, Fanzo J, Miller DD, Pingali P, Post M, Steiner JL, Thalacker-Mercer AE. Production and supply of high-quality food protein for human consumption: sustainability, challenges, and innovations. Ann N Y Acad Sci. 2014;1321:1-19

12. Van Huis A, Van Itterbeeck J, Klunder H, Mertens E, Halloran A, Muir G, et al. Edible insects: future prospects for food and feed security. Rome (IT): Food and Agriculture Organization of the United Nations; 2013. p. 187. FAO Forestry Paper No. 171

13. Jongema, Y. Worldwide list of recorded edible insects. Wageningen (NL): Wageningen University \& Research; 2017 [cited 2017 Jun 04]. 100. Available from http://www.wur.nl/en/Expertise-Services/Chair-groups/Plant-Sciences/ Laboratory-of-Entomology/Edible-insects/Worldwide-species-list.htm.

14. Oonincx DG, van Itterbeeck J, Heetkamp MJ, van den Brand H, van Loon JJ, van Huis A. An exploration on greenhouse gas and ammonia production by insect species suitable for animal or human consumption. PLOS One. 2010; 5(12):e14445.

15. Van Huis A, Oonincx DG. The environmental sustainability of insects as food and feed. A review Agron Sustain Dev. 2017;37:43.

16. Payne C, Scarborough P, Rayner M, Nonaka K. Are edible insects more or less 'healthy' than commonly consumed meats? A comparison using two nutrient profiling models developed to combat over- and undernutrition. Eur J Clin Nutr. 2016;70(3):285-91.

17. Rumpold B, Schlüter O. Nutritional composition and safety aspects of edible insects. Mol Nutr Food Res. 2013 May;57(5):802-23.

18. Van Huis A. Potential of insects as food and feed in assuring food security Annu Rev Entomol. 2013 Jan;58:563-83.

19. Finke MD. Complete nutrient content of four species of feeder insects. Zoo Biol. 2013 Jan;32(1):27-36.

20. Ghana Statistical Service, Ghana Health Service, ICF International. Ghana demographic and health survey 2014. Rockville (MD): GSS, GHS, and ICF International; 2015. p. 530.

21. Anankware JP, Osekre EA, Obeng-Ofori D, Khamala CM. Identification and classification of common edible insects in Ghana. Int J Entomol Res. 2016; 1(5):33-9.

22. Laar A, Kotoh A, Parker M, Milani P, Tawiah-Agyemang C, Soor S, et al. An exploration of edible palm weevil larvae (akokono) as a source of nutrition and livelihood: perspectives from Ghanaian stakeholders. Food Nutr Bull. 2017;38(4):455-67

23. Van Itterbeeck J, van Huis A. Environmental manipulation for edible insect procurement: a historical perspective. J Ethnobiol Ethnomed. 2012;8(1):3

24. Banjo $A D$, Lawal $O A$, Songonuga $E A$. The nutritional value of fourteen species of edible insects in southwestern Nigeria. Afr J Biotechnol. 2006;5(3): 298-301.

25. Bukkens SG. The nutritional value of edible insects. Ecol Food Nutr. 1997; 36(2-4):287-319.

26. Ekpo KE, Onigbinde AO. Nutritional potentials of the larva of Rhynchophorus phoenicis (F). Pak J Nutr. 2005;4(5):287-90

27. Elemo BO, Elemo GN, Makinde M, Erukainure OL. Chemical evaluation of African palm weevil, Rhychophorus phoenicis, larvae as a food source. Insect Sci. 2011;11(1):146.

28. Koffi DM, Cisse M, Koua GA, Niamke SL. Nutritional and functional properties of flour from the palm (Elaeis Guineensis) weevil Rhynchophorus Phoenicis larvae consumed as protein source in south Côte d'lvoire. The Annals of the University Dunarea de Jos of Galati Fascicle VI -Food Technology. 2016: 41(1):9-19. 
29. Okaraonye CC, Ikewuchi JC. Rhynchophorus phoenicis (F) larva meal: nutritional value and health implications. J Biol Sci. 2008;8(7):1221-5.

30. Okunowo WO, Olagboye AM, Afolabi LO, Oyedeji AO. Nutritional value of Rhynchophorus phoenicis (F.) larvae, an edible insect in Nigeria. Afr Entomol. 2017;25(1):156-63.

31. Onyeike EN, Ayalogu EO, Okaraonye CC. (2005). Nutritive value of the larvae of raphia palm beetle (Orcytes rhinoceros) and weevil (Rhyncophorus pheonicis). J Sci Food Agric. 2005;85(11):1822-8.

32. World Health Organization. Joint FAO/WHO/UNU Expert Consultation on Protein and Amino Acid Requirements in Human Nutrition. Geneva, Switzerland: WHO technical report series; no. 935; 2002.

33. Ghana Standards Authority $(\mathrm{GH})$. Fruits, vegetables and derived products—specification for peanut butter and peanut butter crunches. 2nd ed. Accra (GH): Ghana Standards Authority; 2005. Report No: ICS 67.060, Ref. No. GS 49: 2005.

34. Helrich $\mathrm{K}$, editor. Official methods of analysis of the Association of Official Analytical Chemists. 15th ed. Arlington: Association of Official Analytical Chemists, Inc.; 1990. p. 771

35. Schwarz EL, Roberts WL, Pasquali M. Analysis of plasma amino acids by HPLC with photodiode array and fluorescence detection. Clin Chim Acta. 2005;354(1-2):83-90

36. Ortiz EG, Quintero I, Arévalo K. Biodiesel production from three mixes of oils with high free fatty content: quality evaluation and variable analysis. Int J Environ Sci Technol. 2016;13(5):1367-76.

37. Lutterodt H. Protocol for AAS Analysis. Central Laboratory of Kwame Nkrumah University of Science and Technology. Kumasi, Ghana: Kwame Nkrumah University of Science and Technology; May. 3 pages

38. Chapman, H.D., Pratt, P.F. Methods of Analysis for Soils, Plants and Waters. 2nd ed. Determination of minerals by titration method. Berkeley: Division of Agriculture Sciences, University of California; 1982. 169-170.

39. European Committee for Standardization (BE). Foodstuffs. Determination of vitamin A by high performance liquid chromatography. In: Measurement of all-E-retinol and 13-Z-retinol (EN 12823-1). Brussels (BE): European Committee for Standardization; 2014.

40. European Committee for Standardization (BE). Foodstuffs. Determination of vitamin B1 by high performance liquid chromatography (EN 14122). Brussels (BE): European Committee for Standardization; 2006.

41. European Committee for Standardization (BE). Foodstuffs. Determination of vitamin B2 by high performance liquid chromatography (EN 14152). Brussels (BE): European Committee for Standardization; 2006.

42. European Committee for Standardization (BE). Foodstuffs. Determination of vitamin B6 by high performance liquid chromatography (EN 14164). Brussels (BE): European Committee for Standardization; 2008.

43. Nordic Committee on Food Analysis (DK). Folate, biologically active. In: Microbiological determination in milk and milk products with Lactobacillus casei (Method no. 11). Lyngby (DK): Nordic Committee on Food Analysis; 1985. Report No. p. 111.

44. Horowitz W, Latimer GW. Association of Official Analytical Chemists International. Official methods of analysis of AOAC international. 18th ed. AOAC International: Gaithersburg (MD); 2006.

45. European Committee for Standardization (BE). Foodstuffs. Determination of vitamin D by high performance liquid chromatography. In: Measurement of cholecalciferol (D3) or ergocalciferol (D2) (EN 12821). Brussels (BE): European Committee for Standardization; 2009.

46. European Committee for Standardization (BE). Foodstuffs. Determination of vitamin $E$ by high performance liquid chromatography. In: Measurement of A-, B-, $\Gamma$ - and $\Delta$-tocopherol (EN 12822). Brussels (BE): European Committee for Standardization; 2014

47. Institute of Medicine. Dietary reference intakes for energy, carbohydrate, fiber, fat, fatty acids, cholesterol, protein, and amino acids. Washington: The National Academies Press; 2005. 1358 p.

48. Reynolds V, Lloyd AW, Babweteera F, English CJ. Decaying Raphia farinifera palm trees provide a source of sodium for wild chimpanzees in the Budongo forest. Uganda PLoS One. 2009;4(7):e6194.

49. Locke M, Nichol H. Iron economy in insects: transport, metabolism, and storage. Annu Rev Entomol. 1992 Jan;37:195-215.

50. Pham DQ, Winzerling JJ. Insect ferritins: typical or atypical? Biochim Biophys Acta. 2010;1800(8):824-33.

51. Santiago P. Ferrous versus ferric oral iron formulations for the treatment of iron deficiency: a clinical overview. ScientificWorldJournal. 2012;2012:846824.

52. Schumann K, Solomons NW. Perspective: what makes it so difficult to mitigate worldwide anemia prevalence? Adv Nutr. 2017 May 15;8(3):401-8.
53. Bauserman M, Lokankgaka A, Gado J, Close K, Wallace D, Kodondi K, et al. A cluster-randomized trial determining the efficacy of caterpillar cereal as a locally available and sustainable complementary food to prevent stunting and anaemia. Public Health Nutr. 2015;18(10):1785-92.

54. Latunde-Dada GO, Yang W, Aviles MV. In vitro iron availability from insects and sirloin beef. J Agric Food Chem. 2016:64(44):8420-4

55. Fungo R, Muyonga J, Kabehenda M, Kaaya A, Okia CA, Donn P, et al. Contribution of forest foods to dietary intake and their association with household food insecurity: a cross-sectional study in women from rural Cameroon. Public Health Nutr. 2016;19(17):3185-96.

56. Bauserman M, Lokangaka A, Kodondi KK, Gado J, Viera AJ, Bentley ME, et al. Caterpillar cereal as a potential complementary feeding product for infants and young children: nutritional content and acceptability. Matern Child Nutr. 2015;11(4):214-20.

57. Yang Q, Liu S, Sun J, Yu L, Zhang C, Bi J, Yang Z. Nutritional composition and protein quality of the edible beetle Holotrichia parallela. J Insect Sci. 2014;14:139.

58. Michaelsen KF, Hoppe C, Roos N, Kaestel P, Stougaard M, Lauritzen L, et al. Choices of foods and ingredients for moderately malnourished children 6 months to 5 years of age. Food Nutr Bull. 2009;30(3 Suppl):S343-404.

59. Ghosh S. Protein quality in the first thousand days of life. Food Nutr Bull. 2016:37(Suppl 1):S14-21.

\section{Publisher's Note}

Springer Nature remains neutral with regard to jurisdictional claims in published maps and institutional affiliations.
Ready to submit your research? Choose BMC and benefit from:

- fast, convenient online submission

- thorough peer review by experienced researchers in your field

- rapid publication on acceptance

- support for research data, including large and complex data types

- gold Open Access which fosters wider collaboration and increased citations

- maximum visibility for your research: over $100 \mathrm{M}$ website views per year

At BMC, research is always in progress.

Learn more biomedcentral.com/submissions 